\title{
PENGARUH SELF REGULATED LEARNING DAN KARAKTER TERHADAP PRESTASI BELAJAR MAHASISWA PENDIDIKAN BISNIS UNIVERSITAS NEGERI MEDAN
}

\author{
Noni Rozaini ${ }^{1}$, Putri Erinda Yulistya Panjaitan ${ }^{1)}$ \\ 1) Jurusan Ekonomi, Universitas Negeri Medan \\ E-mail: nonirozaini@gmail.com, putrierindayulistya @ gmail.com ${ }^{1)}$
}

\begin{abstract}
Abstrak
Masalah dalam penelitian ini adalah masih rendahnya self regulated learning dan karakter pada mahasiswa yang berpengaruh terhadap prestasi belajar mahasiswa. Penelitian ini bertujuan untuk mengetahui seberapa besar pengaruh self regulated learning dan karakter terhadap prestasi belajar mahasiswa Pendidikan Bisnis stambuk 2017 Fakultas Ekonomi Universitas Negeri Medan. Penelitian ini dilakukan di Fakultas Ekonomi Universitas Negeri Medan dengan populasi seluruh mahasiswa prodi Pendidikan Bisnis stambuk 2017 yang berjumlah 90 orang. Teknik pengambilan sampel yang digunakan adalah teknik Total Sampling. Teknik pengumpulan data yang dilakukan dalam penelitian ini adalah observasi, dokumentasi, dan kuesioner/angket. Uji instrumen penelitian menggunakan uji validitas dan reliabilitas dilakukan dengan menggunakan software SPSS 20 for windows. Teknik analisis data yang di gunakan adalah uji normalitas, uji linearitas, uji multikolinearitas, uji regresi liner berganda. Uji hipotesis menggunakan uji t, uji $\mathrm{F}$, dan uji Koefisien determinasi. Dari hasil uji t menunjukkan bahwa self regulated learning berpengaruh positif dan signifikan terhadap prestasi belajar dengan thitung $>$ ttabel $=$ 4,563 > 1,663 dan nilai signifikani . Karakter berpengaruh positif dan signifikan terhadap prestasi belajar thitung>ttabel $=5,375>1,663$ dan nilai signifikani . Hasil uji $\mathrm{F}$ menunjukkan ada pengaruh yang signifikan antara self regulated learning dan karakter terhadap prestasi belajar dengan nilai dan nilai Sig. $<0,05$. Hasil perhitungan regresi linier berganda diperoleh hasil dengan koefisien determinasi sebesar $43,6 \%$.
\end{abstract}

Kata Kunci : Self Regulated, Learning,Karakter, Prestasi Belajar 


\section{PENDAHULUAN}

Pendidikan dilaksanakan secara terencana dan sistematis agar tujuan pendidikan dapat tercapai sesuai dengan harapan melalui kegiatan pembelajaran yang efektif dan efisien. Kegiatan pembelajaran terdiri atas perencanaan, pelaksanaan dan penilaian. Perencanaan mencakup pembuatan silabus dan Rencana Pelaksanaan Pembelajaran (RPP). Pelaksanaan pembelajaran meliputi kegiatan penyampaian maeri dengan menggunakan strategi atau metode tertentu supaya pembelajaran berjalan efektif. Penilaian dalam kegiatan pembelajaran dilakukan untuk memantau seberapa efektif metode pembelajaran yang digunakan.

Prestasi belajar menjadi salah satu indikator keberhasilan proses pembelajaran sehingga dapat menciptakan manusia yang berkualitas. Hamalik (2002:25) mengemukakan "prestasi belajar adalah hasil belajar yang diperoleh siswa setelah mengikuti program pengajaran dalam bidang studi tertentu, dan diperoleh setelah tejadi interaksi belajar mengajar". Keberhasilan atau ketercapaian prestasi belajar dapat dipengaruhi oleh faktor internal atau faktor eksternal peserta didik. Faktor-faktor penentu keberhasilan prestasi belajar tersebut akan mempengaruhi mahasiswa sebagai peserta dalam mengikuti proses pembelajaran untuk memperoleh prestasi belajar yang baik. Untuk dapat bersaing dalam pasar global, mahasiswa diharapkan menjadi sumber daya manusia yang mampu menguasai bidang keahlian dalam ilmu pengetahuan dan teknologi.

Mahasiswa diposisikan sebagai anggota Sivitas Akademika dewasa yang memiliki kesadaran sendiri dalam mengembangkan potensi diri di Perguruan Tinggi untuk menjadi intelektual, ilmuwan, praktisi, atau professional. Mahasiswa yang mempunyai kualitas sumber daya manusia yang unggul dapat ditunjukkan dengan perilaku disiplin, kreativitas maupun etos kerja yang tinggi dalam mengerjakan tugas dan kewajibannya selama mengikuti proses pembelajaran di perguruan tinggi. Dunia mahasiswa sudah menuntut individu untuk mandiri dalam segala hal. Di kampus, ketika ada tugas, dosen hanya memberikan gambaran umum tentang tugas tersebut, selebihnya dikembalikan kepada mahasiswa atau ketika dosen menjelaskan pelajaran, mereka hanya memberikan jalan atau gambaran umum kepada mahasiswa. Sangat jauh berbeda dengan guruguru ketika di SMA, di mana mereka benarbenar membimbing.

Sejalan dengan hal di atas, berikut ini data prestasi belajar mahasiswa pendidikan bisnis stambuk 2017 Universitas Negeri Medan.
NIAGAWAN Vol 9 No 1 Maret 2020

Tabel 1 Laporan Nilai Semester Genap

Tahun Ajaran 2018/2019 Mahasiswa Pendidikan Bisnis Universitas Negeri Medan stambuk 2017

\begin{tabular}{|c|c|c|c|}
\hline IPK & $\begin{array}{c}\text { Jumlah } \\
\text { Mahasiswa }\end{array}$ & $\begin{array}{c}\text { Perse } \\
\text { ntase } \\
(\boldsymbol{\%})\end{array}$ & Kategori \\
\hline $\begin{array}{c}2,00 \\
-\end{array}$ & 0 & $0 \%$ & $\begin{array}{c}\text { Cukup } \\
\text { Memuaskan }\end{array}$ \\
\hline $\begin{array}{c}2,75 \\
3,50-\end{array}$ & 64 & $76,7 \%$ & Memuaskan \\
\hline $\begin{array}{c}3,51- \\
4,00\end{array}$ & 26 & $23,3 \%$ & $\begin{array}{c}\text { Sangat } \\
\text { Memuaskan }\end{array}$ \\
\hline Total & 90 & $100 \%$ & \\
\hline
\end{tabular}

Sumber : Data Observasi Awal

$$
\text { Proses menempuh pendidikan }
$$

dilembaga perguruan tinggi tentu berbeda dengan lembaga pendidikan sebelumnya. Di perguruan tinggi, materi belajar yang diberikan pada mahasiswa lebih luas dan kompleks dibandingkan materi pelajaran yang diberikan di sekolah menengah. Dengan demikian, dituntut untuk memiliki kemampuan mengatur diri dan perilakunya secara aktif dan mandiri dalam aktivitas belajarnya demi keberhasilan akademiknya.

Mei dan Liyana (2010) mengemukakan dalam hasil penelitiannya terhadap mahasiswa Fakultas Sains Universitas Sains Malaysia, bahwa salah satu faktor yang mempengaruhi prestasi akademik mahasiswa adalah selfregulated learnig. Selain itu, Bell dan Akroyd (Ellianawati dan wahyuni, 2009) menambahkan bahwa self-regulated learning nerupakan bagian dari teori pembelajaran kognitif yang menyatakan bahwa perilaku, motivasi dan aspek lingkungan belajar akan mempengaruhi prestasi seorang pelajar. Munculnya pola pikir, keinginan untuk belajar, serta melakukan tindakan belajar tersebut pada mahasiswa, hal tersebut sudah dapat dikatakan self-regulated.

Dengan sifat self-regulated learning, mahasiswa dituntut untuk memiliki inisiatif sendiri untuk menganalisis kebutuhan, merumuskan tujuan, memilih dan menerapkan strategi pemecahan masalah, menyeleksi sumber yang relevan, serta mengevaluasi diri. Selfregulated learning menjadi salah satu syarat untuk membentuk lulusan yang berkualitas.

Seperti diketahui, aktivitas dalam usaha self-regulated learning dibentuk atas dasar kemauan atau inisiatif individu atau kata sederhanya adalah niat. Namun, self-regulated learning hanya akan terbentuk sempurna menjadi karakter dalam kepribadian seseorang jika kemauan itu diiringi dengan tindakan atau usaha maksimal. Artinya dibutuhkan keuletan, kesabaran dan kedisiplinan dalam belajar mandiri. 
Seperti fenomena yang terlihat di kelas Pendidikan Bisnis stambuk 2017 bahwa masih banyak mahasiswa melakukan kegiatan belajar tanpa melakukan perencanaan, pemantauan, pengontrolan dan evaluasi dalam belajarnya sendiri. Sejalan dengan hal di atas, berdasarkan observasi awal tentang self-regulated learning yang dilakukan peneliti pada 30 mahasiswa pendidikan bisnis stambuk 2017 Universitas Negeri Medan dapat dilihat bahwa hanya 39\% mahasiswa menyelesaikan tugas kuliah sebelum mendekati waktu pengumpulan tugas. Hal tersebut terjadi karena mahasiswa lebih senang menunda-nunda dalam mengerjakan tugas, dan mengerjakan tugas asal-asalan (copy paste, sekedar titip nama), sehingga tugas yang dihasilkan menjadi kurang baik dan optimal. Peneliti juga menemukan ada sekitar 27\% mahasiswa yang tidak memilih belajar dengan sistem kebut semalam (SKS) ketika akan dilaksanakan ujian.

Dapat dilihat juga bahwa hanya $34 \%$ mahasiswa yang memilih bertanya kepada dosen apabila ada materi yang belum dipahami, hal tersebut terjadi karena mahasiswa kurang peduli dengan proses belajar-mengajar di dalam kelas dan mahasiswa kurang aktif di dalam kelas. Fenomena ini mengindikasikan bahwa masih banyak mahasiswa belum memiliki kemampuan dan keterampilan untuk meregulasi dirinya dalam belajar dengan baik, yang berkemungkinan berpengaruh terhadap IPK mereka.

Kemudian faktor lain yang berpengaruh terhadap prestasi belajar mahasiswa adalah karakter. Horraby dan Parnwell (Gunawan, 2012:2) menyatakan karakter adalah kualitas mental atau moral, nama atau reputasi. Menurut Philips (Gunawan,2012:2) karakter adalah kumpulan tata nilai yang menuju pada suatu sistem, yang melandasi pernikahan, sikap dan perilaku yang ditampilkan. Dalam rangka menghasilkan peserta didik yang unggul dan diharapkan proses pendidikan juga senantiasa di evaluasi dan diperbaiki, salah satunya mengenai pentingnya karakter dalam dunia pendidikan di Indonesia.

Karakter dapat diintegrasikan dalam pembelajaran pada setiap mata kuliah. Materi pembelajaran yang berkaitan dengan norma atau nilai-nilai pada setiap mata kuliah perlu dikembangkan, eksplisitkan, dikaitkan dengan konteks kehidupan sehari-hari. Dengan demikian pembelajaran nilai-nilai karakter tidak hanya pada tataran kognitif, tetapi menyentuh pada internalisasi dan pengalaman nyata dalam kehidupan mahasiswa sehari-hari di masyarakat. Banyak yang menyebut bahwa pendidikan telah gagal dalam membangun karakter, sehingga banyak pemuda Indonesia lulusan sekolah dan bahkan sarjana yang pandai menjawab soal ujian, memiliki otak cerdas, berprestasi, tetapi memiliki mental yang lemah, penakut, kurang bertanggung jawab, tidak jujur dan perilakunya tidak terpuji.

Berdasarkan data observasi awal yang dilakukan peneliti kepada 30 responden mahasiswa Pendidikan Bisnis Universitas Negeri Medan stambuk 2017, dapat dilihat bahwa 35\% mahasiswa jujur dalam pengerjaan tugas dan saat melaksanakan ujian, masih rendahnya persentase ini dikarenakan mahasiswa yang mencontek pada saat ujian dan copy paste dalam mengerjakan tugas-tugas. Data juga menunjukkan bahwa rasa hormat mahasiswa terhadap sesama masih rendah, dibuktikan dengan hanya $25 \%$ mahasiswa yang menghormati orang yang lebih tua, seperti kepada dosen dan abang/kakak senior serta etika berbicara yang kurang sopan baik di dalam kelas maupun di luar kelas.

Dapat dilihat juga indikator lain yang menjadi pendorong karakter yaitu peduli terhadap sesama dan lingkungan kampus. Terdapat $40 \%$ mahasiswa yang peduli terhadap lingkungan serta menjaga fasilitas kampus. Hal ini dikarenakan mahasiswa masih membuang sampah sembarangan bahkan meninggalkan sampah di dalam ruangan kelas, serta masih kurangnya sikap menjaga fasilitas kampus dengan baik, misalnya kursi ataupun meja di ruangan kelas.

Universitas Negeri Medan sebagai ikon pendidikan karakter di perguruan tinggi, diharapkan mampu menghasilkan lulusan yang mempunyai karakter yang tangguh, mempunyai bekal kemampuan akademik yang tinggi, pribadi yang kuat, ulet, mandiri, kreatif, dan mempunyai kemampuan manajerial dan kepemimpinan. Dan dalam rangka membentuk lulusan yang berkarakter kuat dan cerdas itu, menurut peneliti mahasiswa pendidikan bisnis harus memahami pentingnya karakter dan self-regulated learning.

\section{TINJAUAN PUSTAKA}

\section{Self Regulated Learning}

Menurut Sugiyana (2015:65) self regulated learning merupakan kesiapan dari individu yang mau dan mampu untuk belajar dengan inisiatif sendiri, dengan atau tanpa bantuan pihak lain dalam hal penentuan tujuan belajar, metode belajar, dan evaluasi prestasi belajar. Sejalan dengan pengertian menurut Zimmerman (Schunk dkk 2008:154) adalah proses dimana mahasiswa mengaktifkan dan mempertahankan kognisi, perilaku, dan perasaan yang mana secara sistematis diorientasikan pada pencapaian tujuan mereka.

Menurut Slameto (2003:23), selfregulated Learning adalah "belajar yang dilakukan dengan sedikit atau sama sekali tanpa bantuan dari pihak luar". Dalam pendapat ini 
self-regulated learning bertanggung jawab atas pembuatan keputusan yang berkaitan dengan proses belajarnya dan memiliki kemampuan untuk melaksanakan keputusan yang diambilnya. Zimmeerman (Lilyano, 2014:213) mengatakan bahwa kemandirian belajar pada mahasiswa dapat digambarkan melalui tingkatan atau derajat yang meliputi keaktifan berpartisipasi baik itu secara metakognisi, motivasional, maupun perilaku dalam proses belajar. Sugilar (2000) menyatakan bahwa karakteristik individu yang memiliki kesiapan belajar mandiri dicirikan oleh : (1) kecintaan terhadap belajar, (2) kepercayaan diri terhadap siswa/mahasiswa, (3) keterbukaan terhadap tantangan belajar, (4) sifat ingin tahu, (5) pemahaman diri dalam hal belajar, dan (6) menerima tanggung jawab untuk kegiatan belajarnya.

Dari uraian di atas, maka dapat disimpulkan bahwa self-regulated learning adalah proses bagaimana seorang peserta didik mengatur pembelajarannya sendiri dengan mengaktifkan kognitif, afektif dan perilakunya sehingga tercapai tujuan belajar.

\section{Karakter}

Karakter secara etimologi "character" (Latin) berarti instrument of narking, "charessein"(Perancis) berarti to engrave (mengukir), "watek" (Jawa) berarti ciri wanci, "watak" (Indonesia) berarti sifat bawaan yang mempengaruhi tingkah laku; budi pekerti; tabiat; perangai.

Philips (Gunawan, 2012:2) karakter adalah kumpulan tata nilai yang menuju pada suatu sistem, yang melandasi pemikiran, sikap dan perilaku yang ditampilkan. Samani dan hariyanto (2012:43) mendefinisikan karakter sebagai nilai dasar yang membangun pribadi seseorang, terbentuk baik karena pengaruh hereditas maupun pengaruh lingkungan, yang membedakannya dengan orang lain, serta diwujudkannya dalam sikap dan perilakunya dalam kehidupan sehari-hari. Pengertian tersebut menekankan dua hal, yakni karakter menjadi pembeda seseorang dengan orang lain, dan karakter diimplementasikan dalam kehidupan sehari-hari. Karakter adalah cara berpikir dan berperilaku yang menjadi ciri khas tiap individu untuk hidup dan bekerjasama, baik dalam lingkup keluarga, masyarakat, bangsa dan Negara. Individu yang berkarakter baik adalah individu yang bisa membuat keputusan dan siap mempertanggungjawabkan tiap akibat dari keputusan yang ia buat. Sejalan dengan pengertian karakter menurut pusat Bahasa Depdiknas adalah bawaan, hati, jiwa, kepribadian, budi pekerti, perilaku, personalitas, sifat, tabiat, tempramen dan watak.

Berdasarkan pendapat di atas maka karakter adalah pemikiran, sikap dan tindakan seseorang dalam melakukan sesuatu yang berasal dari dalam diri seseorang untuk membedakan orang yang satu dengan yang lain dengan kata lain memiliki moral yang baik.

\section{Prestasi Belajar}

Prestasi belajar adalah hal yang tidak dapat dipisahkan dari kegiatan belajar, karena kegiatan belajar merupakan proses, sedangkan prestasi merupakan hasil dari proses belajar. Belajar adalah kegiatan paling pokok yang berarti bahwa beerhasil tidaknya pencapaian tujuan pendidikan banyak bergantung kepada bagaimana proses belajar yang dialami oleh setiap manusia. Belajar membantu manusia untuk berprestasi dengan lingkungannya. Belajar secara sederhana dikatakan sebagai proses perubahan dari belum mampu menjadi mampu yang terjadi dalam jangka waktu tertentu dan sifatnya menetap.

Menurut Winkel (Khairani, 2013:4) menjelaskan bahwa "Belajar adalah proses mental yang mengarah pada penguasaan pengetahuan, kecakapan skill, kebiasaan atau sikap yang yang semuanya diperoleh, disimpan dan dilakukan sehingga menimbulkan tingkah laku yang progresif dan adaptif". Menurut Slamento (2010:2) menyatakan bahwa "belajar adalah suatu proses usaha yang dilakukan seseorang untuk memperoleh suatu perubahan tingkah laku yang baru secara keseluruhan, sebagai hasil pengalamannya sendiri dalam interaksi dan lingkungannya". Menurut Irwanto (2003:36) "memberi batasan untuk belajar, yaitu:

1. Belajar adalah penambahan pengetahuan.

2. Belajar adalah perubahan-perubahan dalam sistem saraf.

3. Belajar sebagai perubahan kelakuan berkat pengalaman dan latihan".

Berdasarkan defenisi di atas, dapat dikatakan secara sederhana bahwa prestasi belajar adalah hal yang dicapai seseorang sebagai akibat dari perbuatan belajar. Nawawi (2002:32) menyatakan bahwa "prestasi belajar adalah tingkat keberhasilan peserta didik dalam mempelajari mata pelajaran yang dinyatakan dalam bentuk nilai yang diperoleh dari hasil belajar mengenai sejumlah mata pelajaran tertentu".

\section{METODE PENELITIAN}

\section{Lokasi Penelitian}

Penelitian ini dilakukan di Fakultas Ekonomi Universitas Negeri Medan yang beralamat di Jalan Willem Iskandar Psr. V Medan 20221. Penelitian ini dilaksanakan pada semester ganjil Tahun Ajaran 2019/2020.

\section{Populasi dan Sampel Penelitian}

Populasi dalam penelitian ini adalah seluruh mahasiswa program studi pendidikan bisnis stambuk 2017 yaitu sebanyak 90 mahasiswa yang tersebar dalam 3 kelas yaitu 
reguler A, reguler B dan Ekstensi. Pengambilan sampel pada penelitian ini, menggunakan total sampling. Yaitu seluruh populasi dijadikan sampel.

\section{HASIL DAN PEMBAHASAN}

\section{Uji Instrumen Penelitian}

Uji instrumen penelitian adalah dengan menggunakan uji validitas angket dan uji reliabilitas angket. Setelah itu dilakukan teknik analisis data menggunakan uji normalitas, uji linearitas dan uji multikolinearitas dan uji hipotesis dengan taraf kepercayaan $95 \%$ dan alpha $5 \%$.

\section{a. Uji Validitas dan Reliabilitas}

Sebelum tes diujikan kepada responden, maka terlebih dahulu diadakan uji instrument angket kepada mahasiswa lain yang memiliki kriteria yang sama untuk mengetahui validitas angket, reliabilitas angket.

\section{1) Uji Validitas}

Angket di uji cobakan kepada mahasiswa pendidikan administrasi perkantoran stambuk 2017 Universitas Negeri Medan. Secara ringkas pada variabel self regulated learning sebanyak 30 butir angket pernyataan dengan responden 30 mahasiswa, setelah diuji validitas melalui SPSS versi 20, diperoleh sebanyak 25 butir angket yang valid.

Untuk variabel karakter sebanyak 30 butir angket pernyataan dengan responden 30 mahasiswa, setelah diuji validitas melalui SPSS versi 20, diperoleh sebanyak 26 angket yang valid.

\section{2) Reliabilitas}

Berdasarkan uji reliabilitas dengan menggunakan rumus Cronbach's Alpha diperoleh hasil pada variable self regulated learning $\left(\mathrm{X}_{1}\right)$ rhitung > rtabel $(0,913>0,361)$. Nilai Cronbach Alpha $=0,913$. Dengan demikian, butir pertanyaan untuk instrumen self regulated learning terbukti reliable.

Pada variabel karakter $\left(\mathrm{X}_{2}\right)$ rhitung > rtable $(0,945>0,361)$. Nilai Cronbach Alpha $=$ 0,945 . Dengan demikian, butir pertanyaan untuk instrumen karakter terbukti reliable.

\section{Teknik Analisis Data \\ a. Uji Normalitas}

Dari hasil uji normalitas menggunakan SPSS didapat nilai signifikansi sebesar 0,984 > 0,05 . Hal ini menunjukkan bahwa data yang digunakan memiliki distribusi normal.

\section{b. Uji Linieritas}

Berdasarkan hasil perhitungan yang pada diperoleh dari SPSS 20 dapat diketahui bahwa self regulated learning $\left(\mathrm{X}_{1}\right)$ memiliki nilai signifikansi Deviation from Linearity sebesar $0,878>0,05$. Dari data tersebut dapat disimpulkan self regulated learning $\left(\mathrm{X}_{1}\right)$ mempunyai hubungan yang linear terhadap prestasi belajar (Y).
NIAGAWAN Vol 9 No 1 Maret 2020

Begitu juga karakter $\left(\mathrm{X}_{2}\right)$ memiliki nilai signifikansi pada Deviation from Linearity sebesar 0,604 > 0,05. Dari data tersebut dapat disimpulkan bahwa karakter $\left(\mathrm{X}_{2}\right)$ mempunyai hubungan yang linear terhadap prestasi belajar (Y).

\section{c. Uji Multikolinearitas}

Dari hasil perhitungan program SPSS 20 diperoleh nilai bahwa nilai tolerance variabel self regulated learning $\left(\mathrm{X}_{1}\right)$ dan karakter $\left(\mathrm{X}_{2}\right)$ $0,930>0,10$. Sementara itu, nilai VIF variabel self regulated learning $\left(\mathrm{X}_{1}\right)$ dan karakter $\left(\mathrm{X}_{2}\right)$ yakni $1,075<10$. Sehingga dapat disimpulkan variabel self regulated learning $\left(\mathrm{X}_{1}\right)$ dan karakter $\left(\mathrm{X}_{2}\right)$ tidak terjadi multikilonieritas

\section{Analisis Regresi Linear Berganda}

Dari hasil perhitungan program SPSS 20 diperoleh nilai koefisien regresi linear berganda untuk $X_{1}=0,282, \quad X_{2}=0,212$, sedangkan konstnta regresi adalah 45,554, sehingga persamaan regresi linear berganda adalah: $Y=45,554+0,282 X_{1}+0,212 X_{2}$

Persamaan regresi di atas mempunyai makna yakni sebagai berikut :

1. Konstanta sebesar 45,554 menyatakan bahwa jika variabel bebas yaitu Self Regulated Leaning dan Karakter dianggap konstan (memiliki nilai (0)) maka nilai variabel terikat (Prestasi Belajar) sebesar 45,554.

2. Koefisien $X_{1}$ sebesar 0,282 menyatakan jika variabel bebas yaitu Self Regulated Leaning $\left(\mathrm{X}_{1}\right)$ naik $1 \%$ maka prestasi belajar $(\mathrm{Y})$ meningkat sebesar 0,282 dengan asumsi variabel bebas yang lain tetap.

3. Koefisien $\mathrm{X}_{2}$ sebesar 0,212 menyatakan jika variabel bebas Karakter $\left(\mathrm{X}_{2}\right)$ naik $1 \%$ maka prestasi belajar (Y) meningkat sebesar 0,212 dengan asumsi variabel bebas yang lain tetap.

\section{Uji Hipotesis}

a. Uji Parsial (Uji t)

Variabel self regulated learning (X1) menunjukkan bahwa $t_{\text {hitung }}>\mathrm{t}_{\text {tabel }} 4,563>1,666$ dengan taraf signifikan $\alpha 0,000<0,05$. Maka hipotesis pertama diterima sehingga dapat disimpulkan bahwa terdapat pengaruh yang signifikan self regulated learning terhadap prestasi belajar Pendidikan Bisnis Fakultas Ekonomi Universitas Negeri Medan Stambuk 2017.

Variabel karakter (X2) menunjukkan bahwa $t_{\text {hitung }}>t_{\text {tabel }}(5,375>1,666)$ dengan taraf signifikan $\alpha 0,000>0,05$. Maka hipotesis kedua diterima sehingga dapat disimpulkan bahwa terdapat pengaruh yang signifikan karakter terhadap prestasi belajar Mahasiswa Pendidikan Bisnis Fakultas Ekonomi Universitas Negeri Medan Stambuk 2017.

\section{b. Uji Simultan (Uji F)}

Pada Pengujian Hipotesis Secara Simultan (Uji F) diperoleh $F_{\text {hitung }}$ sebesar 
33,690 > $\mathrm{F}_{\text {tabel }} 3,10$ dengan taraf sifgnifikan $0,000<0,05$. Maka hipotesis ketiga diterima sehingga dapat disimpulkan bahwa self regulated learning dan karakter secara bersamasama mempunyai pengaruh yang signifikan terhadap prestasi belajar mahasiswa Pendidikan Bisnis Fakultas Ekonomi Universitas Negeri Medan stambuk 2017.

\section{c. Koefisien Determinasi $\left(\boldsymbol{R}^{2}\right)$}

Berdasarkan hasil pengolahan diperoleh nilai Adjusted $\mathrm{R}$ square sebesar 0,436 yang berarti $0,436 \times 100 \%=43,6 \%$ yang berarti bahwa variabel bebas mempunyai kontribusi sebesar nilai $43,6 \%$. Dengan demikian prestasi belajaar mahasiswa dipengaruhi oleh self regulated learning dan karakter sebesar 43,6\% dan sisanya sebesar $56,4 \%$ dipengaruhi oleh faktor-faktor di luar penelitian.

\section{KESIMPULAN DAN SARAN}

Berdasarkan pembahasan diatas maka dapat ditarik kesimpulan bahwa hasil pengujian hipotesis dengan uji t (parsial) diketahui bahwa variabel self regulated learning berpengaruh positif dan signifikan terhadap variabel prestasi belajar mahasiswa. Hasil pengujian hipotesis dengan uji t (parsial) diketahui bahwa variabel karakter berpengaruh positif dan signifikan terhadap variabel prestasi belajar mahasiswa. Hasil pengujian hipotesis dengan uji $F$ (simultan) diketahui bahwa self regulated learning dan karakter berpengaruh secara simultan terhadap prestasi belajar mahasiswa.

\section{Saran}

Adapun saran pada penelitian ini adalah: mahasiswa diharapkan dapat meningkatkan self regulated learning, salah satunya meningkatkan kemauan belajar dari dalam diri sendiri seperti membuat target belajar persemesternya, merangkum setiap materi yang disampaikan dosen dengan menggunakan kalimat sendiri serta memahami tujuan dari materi yang disampaikan dosen. Dengan begitu, mahasiswa dapat membentuk kemampuan dalam berfikir secara realistis, kritis, kreatif, dan fokus dalam pemahaman materi pembelajaran dalam perkuliahan sehingga tercapailah tujuan pembelajaran mahasiswa tersebut. Mahasiswa diharapkan mampu menanamkan nilai-nilai karakter dan membiasakan diri dengan karakter yang baik. Hal ini bisa di mulai dengan perilaku mahasiswa yang jujur ketika saat mengerjakan tugas atau ujian, kemudian bertanggung jawab dengan tugas-tugas yang diberikan dosen seperti tidak menunda-nunda dalam mengerjakan tugas. Dengan begitu maka akan berdampak terhadap peningkatan prestasi belajar mahasiswa. Bagi instansi pendidikan terkhusus Fakultas Ekonomi
NIAGAWAN Vol 9 No 1 Maret 2020

Universitas Negeri Medan diharapkan turut memberikan pembinaan mengenai karakter yang baik, seperti menerapkan pembelajaran karakter didalam perkuliahan sehingga sehingga mahasiswa dapat membiasakan diri dengan karakter yang baik dalam proses pembelajaran maupun di luar pembelajaran. Bagi peneliti selanjutnya yang tertarik untuk melakukan penelitian dengan tema yang sama diharapkan mempertimbangkan $56,4 \%$ variabel yang lain berpengaruh terhadap prestasi belajar.

\section{REFERENSI}

Alimin, Arip. (2014). Pengaruh pndidikan karakter terhadap prestasi belajar mata pelajaran produktif siswa kompetensi keahlian teknik elektronika industry SMKN 1 Losarang Kabupaten Indramayu. Skripsi: Universitas Negeri Yogyakarta.

Arikunto, S. 2017. Prosedur Penelitian : Suatu Pendekatan Praktik. Jakarta: Rineka Cipta.

Ambarita, Biner. 2013. Kebijakan Pendidikan Karakter Di Unimed. Medan: Universitas Negeri Medan.Hamalik, Oemar. 2002. Proses Belajar Mengajar. Jakarta: Bumi Aksara.

Cobb, R.J., 2003. The relationship between selfregulated learning behaviors and academic performance in web-based course. Dissertation, Virginia: Blacksburg.

Ellianawati, S Wahyuni. 2010. Pemanfaatan Model Self Regulated Learning Sebagai Upaya Peningkatan Kemampuan Belajar Mandiri Pada Mata Kuliah Optik. Jurnal Pendidikan Fisika Indonesia 6 (2010) 35-59, ISSN:16931246.

Gede, Raka dkk. 2011. Pendidikan Karakter Di Sekolah. PT. Elek Media Komputindo Gramedia. Jakarta.

Gunawan, Heri. 2012. Pendidikan Karakter, Konsep dan Implementasi. Bandung: Alfabeta.

Hamalik, Oemar. 2002. Psikologi Belajar dan Mengajar. Bandung: Sinar Baru Algesindo.

Hamdani. 2010. Strategi Belajar Mengajar. Bandung: Pustaka Setia.

Harie dan Widyanto. (2019). Pengaruh Self Regulated Learning dan Self Control Terhadap Hasil Belajar Bahasa Indonesia. Jurnal Dimensi Pendidikan dan Pembelajaran. Vol 7 ISSN 20033800 .

Hasbullah. 2014. Sistem Pendidikan Nasional Jakarta: Rajawali Pers.

Kurniawan, R. 2013. Hubungan Antara SelfRegulated Learning Dengan Prokrastinasi Akademik Pada 
Mahasiswa Jurusan Psikologi. Semarang.

Kemdiknas, 2010. Desain Induk Pendidikan Karakter. Jakarta: Kementrian Pendidikan Nasional.

Khairani, Makmun. 2013. Psikologi Belajar. Yogyakarta: Aswaja Presindo.

Kiyani, 2012, "The Relationship Between Brand Trusrt, Customer Satisfaction and Customer Loyalty." Interdiciplinery journal of comtempory recear business 4(1): 489-502.

Latipah, Eva. (2010). Strategi Self Regulated Learning dan Prestasi Belajar: Kajian Meta Analisis. Jurnal Psikologi. Volume 37, No. 1, Juni 2010:110-129.

Listriani dan Intan. 2017. Ensiklopedia pendidikan. Medan. Media.

Masrura, Inaya, Sitti \& Jirana. (Oktober 2016). Pengaruh Karakter dan Latar Belakang Peserta Didik Terhadap Hasil Belajar Biologi SMPN 1 Tinambung. Prosiding Seminar Nasional Biologi / IPA dan Pembelajarannya 1127-1131.

Najib, A, \& Achdiyah, B, N. 2012. Pengaruh Pendidikan Karakter Terhadap Hasil Belajar Siswa. Jurnal Ekonomi dan Pendidikan, Volume 9, 102-108.

Ormrod. Ellis Jeanne. 2008. Psikologi Pendidikan. Jakarta : Erlangga.

Prayekti, dkk. (November 2016). Pengaruh Kemandirian Belajar Terhadap Hasil Belajar Mahasiswa Bidik Misi Masa Registrasi 2016. Prosiding Temu Ilmiah Nasional Guru (Ting) VIII 143-154.

Rahmiyati, Anis. (2017). Pengaruh Self Regulated Learning Terhadap Prestasi Belajar Siswa Kelas X Pada Mata Pelajaran Ekonomi. Artikel Penelitian, $1-11$.

Salahudin dan Irwanto. 2013. Pendidikan Karakter. Bandung: Pusaka Setia.

Samani, Muchlas dan Hariyanto. 2012. Pendidikan Karakter. Bandung: PT Remaja Rosdakarya.

Sarwono, J. (2006). Metode Penelitian Kuantitatif dan Kualitatif. Yogyakarta: Graha Ilmu.

Schunk, H.D., Pintrich, P. R, dan Mecce. L.J. 2008. Motivational In Education: theory, research, and application. Ohio: Pearson Press.

Septiyaningsih, Sri. (2017). Pengaruh Aktivitas Belajar dan Kemandirian Belajar Terhadap Prestasi Belajar Mahasiswa. Jurnal Pendidikan dan Ekonomi, 6:3.

Setiyorini, E. (2014). Pengaruh Modal Budaya, Pendidikan Karakter dan Kepribadian Siswa Terhadap Prestasi Belajar Mata Pelajaran Ekonomi. Economic Education Analysis, 530-535.
Slameto. 2003. Belajar dan Faktpr-Faktor yang Mempengaruhinya. Jakarta : Rineka Cipta.

Slameto. 2010. Belajar dan faktor-faktor yang mempengaruinya. Jakarta: Rineka Cipta.

Slameto. 2013. Belajar dan faktor-faktor yang mempengaruhinya. Jakarta: Rineka Cipta.

Sugiyana. (2015). Pengaruh Self-Regulated Learning, Self-Efficacy dan Perhatian Orangtua Terhadap Prestasi Belajar Matematika Siswa. Psikopedagogia Vol.44, No.1 63-72.

Sugiyono. 2012. Metode Penelitian Pendidikan. Bandung:Alfabeta.

Sugiyono. 2010. Metode Penelitian Pendidikan: Pendekatan Kuantitatiff, Kualitatif, dan $R \& D$. Bandung:Alfabeta.

Sugiyono. 2013. Metode Penelitian Kuantitatif Kulitatif dan $R \&$ \& D. Bandung:Alfabeta.

Sugiyono. 2016. Metode Penelitian Kuantitatif Kualitatif dan $R \& D$. Bandung:Alfabeta.

Suryabrata, Sumadi. 2013. Psikologi Kepribadian. Jakarta: Raja Grafindo Persada.

Susanto, Hadi. 2006. Mengembangkan Kemampuan Self Regulated Learning untuk Meningkatkan Keberhasilan Akademik Siswa. Jurnal Pendidikan Penabur Nomor 7, Halaman 64-71.

Wolters, C. A., Pintrich, P. R., \& Karabenick, S. A. 2003. Assessing academic selfregulated learning. Makalah disajikan dalam konferensi pada Indicators of Positive Development: Definitions, Measures, and Prospective Validity. Michigan, USA.

Yaumi, Muhammad. 2012. Pilar-Pilar Pendidikan Karakter. Artikel Scholar.

Zimmerman, B. J. 2008. Investigating selfregulated an motivation: Historical background, methodological developments, and future prospect. American Educational Research Journal, 45(1), 166-183 